in the Gold Coast at the West African Research Institute, and with world production and consumption of cocoa. In addition, there are eight appendixes dealing with certain technical aspects of growing cocoa, including soil surveying, farm costing, propagator design and small-scale fermentation. A notable feature of the book is the large number of excellent photographs and ten colour plates. Selected reference lists are given at the end of each chapter, and there is a good general index.

The renewed interest during recent years in the growing of cocoa and in the results of scientific research on problems connected with it has created an urgent need for a book such as this, and its author deserves the highest commendation for his successful attempt to perform a useful but difficult task.

\section{THE ENGLISH CLIMATE}

\section{The English Climate}

By Dr. C. E. P. Brooks. Pp. $x+214$. (London: English Universities Press, Ltd., 1954.) 12s. 6d. net.

$\mathrm{I}^{\mathrm{N}}$ this engagingly written volume Dr. C. E. P. Brooks describes the climate of Britain in relation to the major factors controlling it as well as the various weather processes and seasonal vicissitudes which make it up. Local climates are considered in much detail, largely from the human point of view in relation to such matters as bracing and relaxing conditions and the suitability of places for residence, holidays and retirement. In a discussion of 'sultry' conditions as defined by certain limits of temperature and relative humidity, there is an obscure statement on p. 114 to the effect that exposure to sunshine raises the body temperature by several degrees. This presumably refers to the external surface temperature, not the internal blood temperature, which would indicate high fever. In the chapter on "Fog and Soot" much prominence is given to the disastrous 'smog' of December 1952. The heavy death-rate from bronchitis and pneumonia is apparently attributed in the main to sulphur dioxide and soot; but it should be noted that some modical authorities maintain that, if this long-continued four-day fog had not been associated with freezing temperature in London, the mortality would have been notably less. No reference is made in this chapter to modern smoke-abatement practices and changed methods of domestic heating as bearing on the experience of the older generation that London fogs to-day have lost the sooty blackness of Victorian times.

Dr. Brooks's review of notable weather events in modern times, including storms, droughts, frosts and heat spells, leaves little unnoticed. There is no mention, however, of the prolonged intense frost in southern England during November-January 189091, though the famous blizzard in Devon and Cornwall which followed in March is accorded full honours. The author is right in maintaining that, while English weather is sometimes unpleasant, wild and even dangerous, these are more than compensated by many delightful moods. Essentially moderate, a stimulating variety is, he declares, to be reckoned among its greatest assets. To the more imponderable assets one would add the changeful skies and picturesque cloud scenery to which, indeed, many generations of our landscape painters have done ample justice.

L. C. W. Bonacina

\section{SOCIAL MEDICINE}

The Meaning of Social Medicine

By Iago Galdston. Pp. xii + 137. (Cambridge, Mass. : Harvard University Press ; London : Oxford University Press, 1954. Published for The Commonwealth Fund.) 22s. net.

OURING the past sixteen years there has been much talk of social medicine, though its advocates are not always clear as to its scope and differentiation from clinical, preventive and 'socialized' medicine. This book records the inquiries of the Secretary of the Medical Information Bureau of the New York Academy of Medicine into the subject.

In 1848 Jules Guérin seems to have coined the expression "social medicine", and defined it "as the congregate function of the separate activities differently termed medical police, public hygiene and legal medicine". Many authorities regard social medicive as the sum total of all and everything that bears on medicine and the social organism. The late Prof. Roné Sand gave a list of numerous components of the medical and sociological sciences which comprise social medicine. All these can be of use to the subject. But social medicine itself "must be and is something more than the sum of the sciences". It is not a new name for an old discipline.

When the chair of social medicine with its Institute was founded at Oxford in 1942, the main purposes were set out as follows: "To investigate the influence of social, genetic, environmental and domestic factors on the incidence of human disease and disability. To seek and promote measures, other than those usually employed in the practice of remedial medicine, for the protection of the individual and of the community against such forces as interfere with the full development of man's mental and physical capacity".

The subject was so attractive that the late John Ryle forsook the regius chair of physic at Cambridge to become the professor of social medicine at Oxford. Under bis direction, important investigations were carried out; but when he died social medicine languished in the University. This is not surprising, for the science of social medicine is still in the making, and stern economists desire to see results which justify expenditure. Nevertheless, Oxford's example, initiated in 1939, was followed by a chair of social medicine at Birmingham and a lectureship at Sheffield, while the chair of public health at Edinburgh became the chair of public health and social medicine.

In social medicine there is a vast field of potential research, in many respects still a virgin and unexplored territory. The wide conception of the subject demands access to many branches of learning. Hence its essential growth should be in a university. Dr. I. Galdston desires similar experiments to be made in the United States. He writes: "It would be well if one or more medical schools, preferably those closely associated with universities or schools of liberal arts and in close relations with hospitals ... would institute an experiment in the gestalt of social medicine. . . . It is not at all unlikely that it might have as great an effect as did that other experiment in medical education initiated by Welch and Osler some sixty years ago". To British pioneers in social medicine and to those who promoted the first chair of social medicine in Great Britain, these words are welcome and encouraging.

Arthur S. MacNaLty 